\title{
$1 \mathrm{Ea} 08$
}

疲労測定における極限法の不確定範囲に関する研究(1)

\author{
林喜男(慶応大・工) ○武田正治(武蔵工大・工) \\ Study on the Interval of Uncertainty of the Method of Limit in a Measurement of Fatigue \\ Y.Hayashi(Keio Univ., Fac.of Eng.) \\ M.Takeda(Musashi Inst.of Tech.,Fac.of Eng.)
}

\section{1.はじめに}

疲労の測定はいろいろな手法を用いている。 簡易な手法としてフリッカー測定が多用されて いるが被験者の熟練問題と測定時の測定される ことの影響による一時光進などにより思うよう な結果が得られないことが多い。測定を失敗す る要因の一つとして、オーバーシュートが考え られる。ちらつきがなく静止したと被験者が意 思決定し、ボタンを押すまで測定装置側では周 波数が上昇または下降しつつあるわけであるか ら、この時間遅れ分が測定值に影響をおよぼす ことになる。このオーバーシュートにより上昇 または下降のフリッカー值が作業前值と作業高 值の間で変化がなければオーバーシュート分が 一定であるため問題とはならないが疲労による ボタン操作に遅机が生じると仮定するとオーバ ーシュート分の值のズレが上昇系列では周波数 のきり上がり、下降系列では切りさがりとなる。 本実験室でVDT作業者 10 名のデータ入力作 業負荷時、毎秒 2 秒きざみ巾のフリッカー測定 において、ケース A は無負荷時、ケース B はデ ータを表にして視覚負荷とし、ケースCはデー 夕を音声にして聴覚負荷とし、デー夕を極限法 によって測定し、上昇系列平均と下降系列平均 の差を不確定範囲とし、その不確定範囲の推移 をプロットしたものが図 1 である。本図から負 荷の累積効果の形で不確定範囲が顕著に上昇し ていることがわかる。負荷作業は50分をユニッ 卜として 1 日 7 回測定時間をはさんで行う苛酷 なものであるにもか>わらずフリッカー值の低
下率は $-3.83 \%$ と被験者の疲労感との間に大き い差が見られた。しかし、不確定範囲の值は大 きく変化しており、この点に着眼し極限法にお ける上昇および下降のフリッカー周波数のきざ み巾を変化させ、不確定範囲の変動について実 験を行ない、考察した。

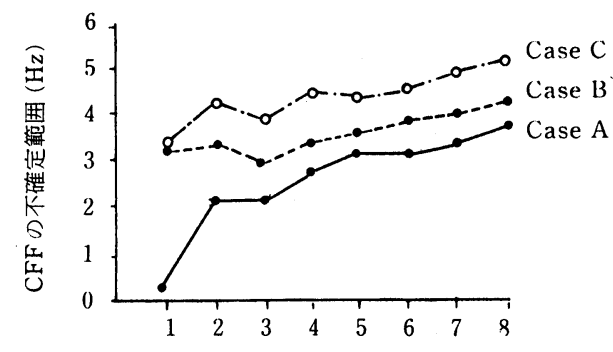

図 1 CFFの不確定範囲 回 数

\section{目的}

疲労をフリッカー值で表示する場合、極限法 の上昇および下降系列の測定值を利用して行な うものとし、上昇抢よび下降の毎秒の変化巾を 変えることにより、不確定範囲および平均值の 挙動を実験により調べる。

\section{実験方法}

被験者：22〜23才男子 5 名

実験室：暗騒音を充分にコントロールした音 響測定用実験室

測定装置：竹井機器工業製 型番 S -89097 にP C-9801との間にインターフェイスボード を装着し、P C - 9801からフリッカー変化速度 をコントロール可能 $(0.1 \mathrm{~Hz})$ にした装置。

実験 1 ：無作業時のフリッカー測定を上昇お 
よび下降10回を 1 組みとして18回繰り返し、測 定値に傾向や同期変動がないことを確証し、被 験者の個人値とした。

実験 $2 ： 5$ 名の被験者のフリッカー値を基準 として提示光の周波数変化のきざみ幅を $3.2 \mathrm{~Hz}$ 、 $1.6 \mathrm{~Hz} 、 0.8 \mathrm{~Hz} 、 0.4 \mathrm{~Hz} 、 0.2 \mathrm{~Hz}$ の 5 ステップに 可変とし、この可変の状態を上昇扔よび下降系

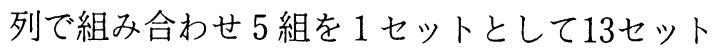
行った。この内最初の 1 セットをトライアルと

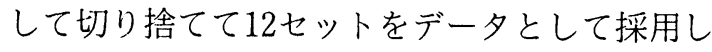
た。

実験 3 ：被験者 2 名のVDT作業負荷時のデ ータがあったので、この 2 名にVDT作業負荷を 課し、実験 2 のフリッカー測定を実施した。 実験結果

\section{実験 1}

フリッカー値の個人値として表 1 となった。 この結果から個人差が大きく、各被験者別にデ ータを処理することとした。

表 1 フリッカー実験 1 測定値

\begin{tabular}{|c|c|c|c|c|c|c|}
\hline & 被験者 $\mathrm{A}$ & 被験者 B & 被験者 C & 被験者D & 被験者 $\mathrm{E}$ \\
\hline \multirow{2}{*}{ 上 } & データ数 & 180 & 180 & 180 & 180 & 180 \\
\hline & 非均 & 35.29 & 42.65 & 35.65 & 37.58 & 34.57 \\
\hline 昇 & 標準偏差 & 1.46 & 2.59 & 1.08 & 1.27 & 1.35 \\
\hline \multirow{2}{*}{ 下 } & デー夕数 & 180 & 180 & 180 & 180 & 180 \\
\hline & 平 均 & 33.74 & 38.34 & 33.92 & 36.02 & 30.26 \\
\hline 降 & 標準偏差 & 1.51 & 2.84 & 1.5 & 1.39 & 1.58 \\
\hline \multicolumn{2}{|r|}{$C F F$} & 34.52 & 40.50 & 34.79 & 36.80 & 32.42 \\
\hline
\end{tabular}

\section{実験 2}

被験者別、きざみ幅別のフリッカー値を示せ ば表 2 のとおりである。このデータから個人差 ときざみ幅で分散分析を行なった結果、個人差 は高度に有意、きざみ幅は有意ということにな つた。被験者別の不確定範囲を観察すると全体 として刻み幅を小さくするほど值は小さくなる。 しかし被験者 $\mathrm{A}$ 抢よび $\mathrm{B}$ は刻み幅が $1,6 \mathrm{~Hz}$ とな ったところから上昇抢よび下降系列の值が上下 で交わった。C、D、Eの被験者は不確定範囲 で狭くなり、典型的な例としてD0)不確定範囲 のグラフを示せば図 2 のとおりである。
表 2 各ステップ毎被験者別フリッカー值

\begin{tabular}{|l|c|c|c|c|c|}
\hline & $3.2 \mathrm{~Hz}$ & $1.6 \mathrm{~Hz}$ & $0.8 \mathrm{~Hz}$ & $0.4 \mathrm{~Hz}$ & $0.2 \mathrm{~Hz}$ \\
\hline 被験者 $\mathrm{\Lambda}$ & 37.60 & 37.58 & 38.23 & 38.45 & 38.17 \\
\hline 被験者 $\mathrm{B}$ & 38.96 & 37.68 & 38.33 & 38.09 & 38.04 \\
\hline 被験者 $\mathrm{C}$ & 37.59 & 37.58 & 37.93 & 38.16 & 37.58 \\
\hline 被験者D & 42.21 & 42.25 & 43.19 & 43.30 & 42.37 \\
\hline 被験者 $\mathrm{E}$ & 35.10 & 35.25 & 35.93 & 36.38 & 36.50 \\
\hline
\end{tabular}

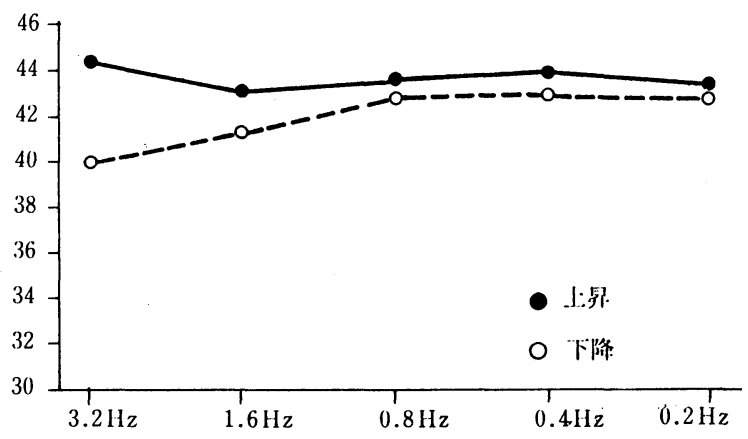

図2 各ステップ毎被験者別の CFF值 (被験者D)

\section{実験 3}

上昇および下降系列の刻み幅を変化させるこ とが不確定範囲を狭くすることに有効であるこ とが確認できた。しかもVDT作業負荷による実 験で被験者のフリッカー値の低下率が刻み幅 $0.8 \mathrm{~Hz}$ においてー6.98\%となり、疲労感に近い 数值が得られた。

\section{結論}

疲労測定時における測定方法は単時間で、簡 易な方法を必要とするため、極限法が多用され ている。しかし極限法においては刻み幅の変化 のさせ方でオーバーシュート分が測定誤差とな って表示される。それが不確定範囲となってい る。これが本実験によって確認できた。刻み幅 のコントロールによってフリッカー測定の有効 性を高める方法の一つであるといえる。今後、 不確定範囲がプラスやマイナスといった分布に なるのか、被験者の意思決定の違いによって変 化速度を変えた方がよいのかなど実験を進める ことにする。 